University of Nebraska - Lincoln

DigitalCommons@University of Nebraska - Lincoln

USDA National Wildlife Research Center - Staff Publications
U.S. Department of Agriculture: Animal and Plant Health Inspection Service

November 2001

\title{
The demographic response of bank-dwelling beavers to flow regulation: a comparison on the Green and Yampa rivers
}

\author{
Stewart W. Breck \\ USDA/APHIS/WS National Wildlife Research Center, stewart.w.breck@aphis.usda.gov \\ Kenneth R. Wilson \\ Colorado State University, kenneth.wilson@colostate.edu \\ Douglas C. Anderson
}

Follow this and additional works at: https://digitalcommons.unl.edu/icwdm_usdanwrc

Part of the Environmental Sciences Commons

Breck, Stewart W.; Wilson, Kenneth R.; and Anderson, Douglas C., "The demographic response of bankdwelling beavers to flow regulation: a comparison on the Green and Yampa rivers" (2001). USDA National Wildlife Research Center - Staff Publications. 527.

https://digitalcommons.unl.edu/icwdm_usdanwrc/527

This Article is brought to you for free and open access by the U.S. Department of Agriculture: Animal and Plant Health Inspection Service at DigitalCommons@University of Nebraska - Lincoln. It has been accepted for inclusion in USDA National Wildlife Research Center - Staff Publications by an authorized administrator of DigitalCommons@University of Nebraska - Lincoln. 


\title{
The demographic response of bank-dwelling beavers to flow regulation: a comparison on the Green and Yampa rivers
}

\author{
Stewart W. Breck, Kenneth R. Wilson, and Douglas C. Andersen
}

\begin{abstract}
We assessed the effects of flow regulation on the demography of beavers (Castor canadensis) by comparing the density, home-range size, and body size of bank-dwelling beavers on two sixth-order alluvial river systems, the flow-regulated Green River and the free-flowing Yampa River, from 1997 to 2000. Flow regulation on the Green River has altered fluvial geomorphic processes, influencing the availability of willow and cottonwood, which, in turn, has influenced the demography of beavers. Beaver density was higher on the Green River (0.5-0.6 colonies per kilometre of river) than on the Yampa River (0.35 colonies per kilometre of river). Adult and subadult beavers on the Green River were in better condition, as indicated by larger body mass and tail size. There was no detectable difference in homerange size, though there were areas on the Yampa River that no beavers used. We attribute the improved habitat quality on the Green River to a greater availability of willow. We suggest that the sandy flats and sandbars that form during base flows and the ice cover that forms over winter on the Yampa River increase the energy expended by the beavers to obtain food and increase predation risk and thus lowers the availability of woody forage.
\end{abstract}

\begin{abstract}
Résumé : Nous avons évalué les effets du contrôle du débit sur la démographie du Castor du Canada (Castor canadensis), de 1997 à 2000, en comparant la densité, le domaine et la taille du corps chez des castors vivant sur les rives des systèmes alluviaux de deux cours d'eau de sixième ordre, la rivière Green, à débit contrôlé, et la rivière Yampa, aux eaux non contrôlées. Le contrôle des eaux de la rivière Green a modifié les processus géomorphiques fluviaux, influençant la disponibilité des saules et des peupliers, ce qui a affecté la démographie des castors. La densité des castors était plus élevée sur la rivière Green $(0,5-0,6$ colonie par kilomètre de rivière) que sur la rivière Yampa $(0,35$ colonie par kilomètre de rivière). Les castors adultes et sub-adultes de la rivière Green étaient en meilleure condition physique, tel qu'indiqué par leur masse plus grande et la taille plus importante de leur queue. Il n’y avait pas de différences décelables dans les dimensions des domaines sur les deux rivières, mais certaines zones de la rivière Yampa n'étaient pas utilisées par les castors. Nous attribuons l'amélioration de la qualité des habitats sur la rivière Green à la disponibilité plus grande de saules. Nous croyons que les plateaux et les haut-fonds sablonneux qui se forment pendant l'étiage et la couverture de glace qui se développe en hiver dans la rivière Yampa augmentent l'énergie dépensée par les castors pour se trouver de la nourriture et amplifient les risques de prédation et, de ce fait, diminuent la disponibilité de la nourriture ligneuse.
\end{abstract}

[Traduit par la Rédaction]

\section{Introduction}

Annual spring flooding is an important disturbance that regulates the functioning of riparian ecosystems on many arid-land rivers in the western U.S.A. (Knopf et al. 1988; Scott et al. 1997). Human alteration of the flood regime through the construction and operation of large dams has caused considerable changes in the distribution and abundance of plants and animals associated with the riparian community (Nilsson et al. 1991; Nilsson and Dynesius 1994; Kingsford 2000). Understanding how and why species re-

Received May 1, 2001. Accepted September 7, 2001.

Published on the NRC Research Press Web site at http://cjz.nrc.ca on November 6, 2001.

S.W. Breck ${ }^{1,2}$ and K.R. Wilson. Department of Fishery and Wildlife Biology, Colorado State University, Fort Collins, CO 80523, U.S.A.

D.C. Andersen. United States Geological Survey, D-8220, P.O. Box 25007, Denver, CO 80225, U.S.A.

${ }^{1}$ Corresponding author (e-mail: Stewart.W.Breck@aphis.usda.gov). ${ }^{2}$ Present address: National Wildlife Research Center, 4101 LaPorte Avenue, Fort Collins, CO 80521, U.S.A. spond to flow regulation will be important in the effort to maintain or restore key components of riparian ecosystems on managed rivers.

For example, the decline of cottonwood trees (Populus spp.) across many western rivers (see Cooper et al. 1999) is a major concern because of the unique biological and aesthetic value of cottonwoods (Howe and Knopf 1991). Flow regulation affects cottonwoods by altering both abiotic and biotic processes that are required for regeneration (Busch and Smith 1995; Scott et al. 1996; Andersen and Cooper 2000). Beaver (Castor canadensis) herbivory is a biotic process that can limit populations of certain tree species (Barnes and Dibble 1988; Johnston and Naiman 1990). Therefore, understanding how beaver populations respond to flow regulation may be important in the effort to restore cottonwood trees.

Little is known about the impact of flow regulation on the population biology of beavers. Some researchers speculate that stable flows decrease beaver populations by decreasing the amount of forage (Nilsson and Dynesius 1994). Others predict that stable flows will increase beaver populations by increasing the number of denning sites (Lesica and Miles 1999). The validity of these predictions is hard to assess, in 
Fig. 1. Locations of study areas and Flaming Gorge Dam on the Green and Yampa rivers in northwestern Colorado, $1997-1999$.

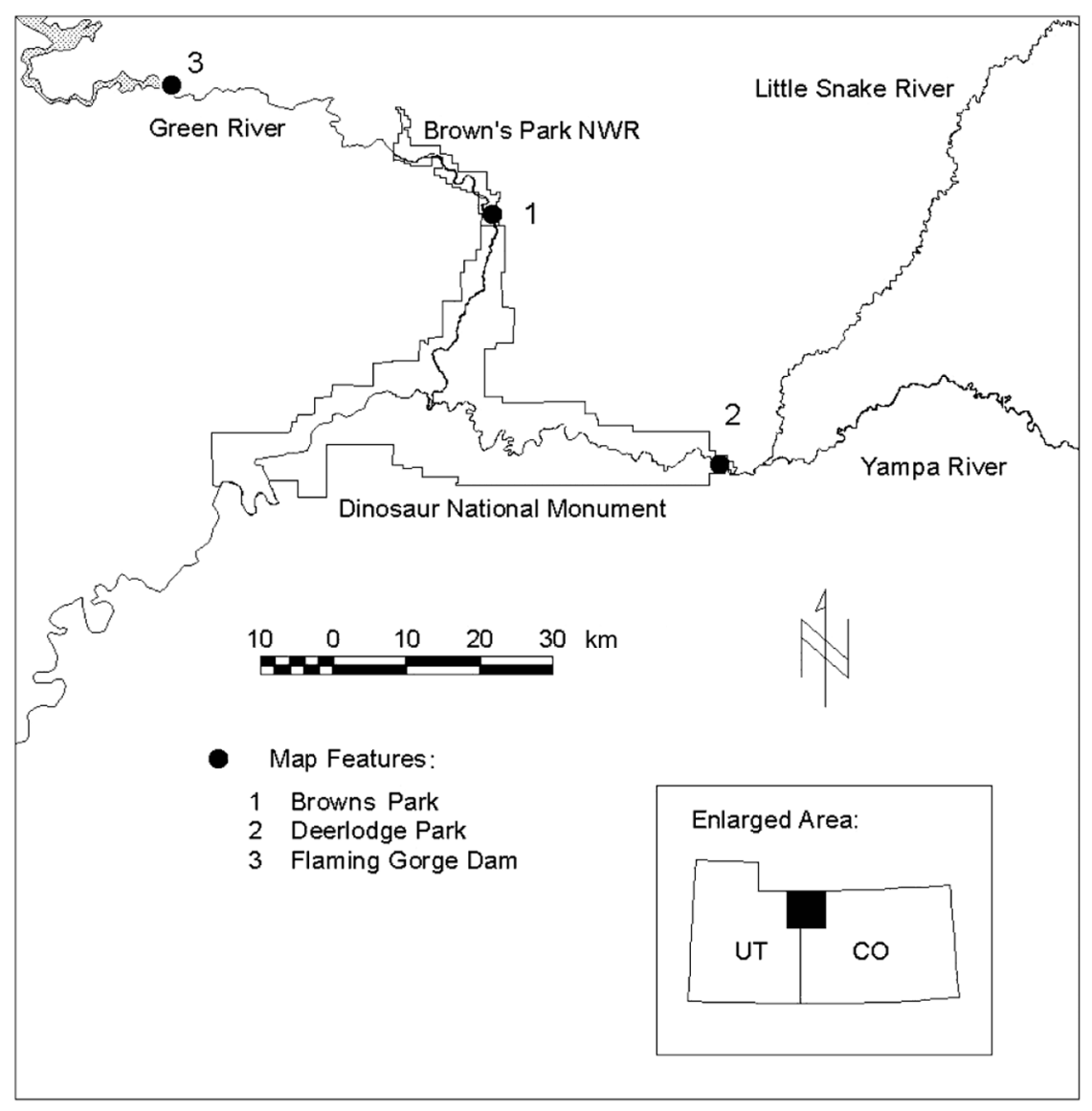

part because of the lack of autecological knowledge concerning bank-dwelling beavers in large-order rivers. Knowledge of density has been garnered from studies based on trapping data (Vanden Berge and Vohs 1977) and observational data (Strong 1982). But to our knowledge, no study has utilized radiotelemetry to assess important demographic and behavioral parameters (e.g., survival rates, home-range sizes, movement patterns) that are important in assessing and explaining a response to flow regulation.

We used a demographic-response design (Garshelis 2000) to obtain autecological data on bank-dwelling beavers and assess how beaver populations have responded to specific changes in the riparian ecosystem resulting from flow regulation. Specifically, we compared body size, density, and homerange size of beavers on the flow-regulated Green River with those of beavers on the free-flowing Yampa River. Because of the dramatic decline of Fremont cottonwood (Populus deltoides Marshall ssp. wizlizenii) recruitment on the Green River (Cooper et al. 1999; Merritt and Cooper 2000) and because beavers utilize cottonwoods (Strong 1982; McGinley and Whitham 1985), we predicted that ( $i$ ) beaver population density would be lower on the Green River and (ii) beaver home ranges would be larger on the Green River.

\section{Study area}

The Green and Yampa rivers are major tributaries in the Colorado River system. We conducted our study on alluvial sections of these rivers above their confluence in northwestern Colorado (Fig. 1) (for a detailed description see Cooper et al. 1999; Merritt and Coo- per 2000). On the Yampa River we were confined to a $10-\mathrm{km}$ section from the confluence of the Little Snake River to the beginning of Yampa Canyon in Dinosaur National Monument. On the Green River (based on aerial photographs) we selected a similar 10-km section within Browns Park National Wildlife Refuge that had been studied since 1994 as part of a long-term study of ecological changes resulting from river regulation (Falck 1996; Miller 1998; Cooper et al. 1999; Andersen et al. 2000). Both river sections are sixth-order alluvial systems and neither had been trapped for beavers for at least 3 years prior to, or during, the study.

Our study was an observational field study as described by Eberhardt and Thomas (1991, pp. 64-65), the obvious limitation being the lack of control over allocation of treatments (i.e., unregulated river versus regulated river) to experimental units (rivers). In addition, it was not possible to have replicate rivers, because the Yampa River is the last relatively unregulated river in the Colorado River system. The primary assumption of this study was that prior to 1962, when Flaming Gorge Dam was completed, the Green and Yampa rivers had similar flow regimes and maintained similar ecosystems within the study sections. The following facts support this assumption: (i) flow regimes (including peak flows, base flows, and timing of flows) on the pre-dam Green and Yampa rivers were similar (Fig. 2), (ii) elevations are similar (1633 $\mathrm{m}$ on the Green River and 1707 m on the Yampa River), and (iii) woody vegetation was similar and was characterized primarily by Freemont cottonwood and sandbar willow (Salix exigua) (Copper et al. 1999; Merritt and Cooper 2000).

Flow regulation (i.e., the reduction of a flood pulse and the increase in base flows; Fig. 2) on the Green River has caused a number of changes in fluvial geomorphology downstream of the dam (Andrews 1986; Merritt and Cooper 2000), including the development of instream islands and the loss of point bars in Browns Park 
Fig. 2. Average yearly flow of the Green River pre-dam (1923-1962) and post-dam (1962-1994) and the Yampa River (1923-1996). Peak and base flows on the two rivers were similar prior to the completion of Flaming Gorge Dam. Flow regulation on the Green River since 1962 has resulted in the elimination of peak flow and an increase in base flow.

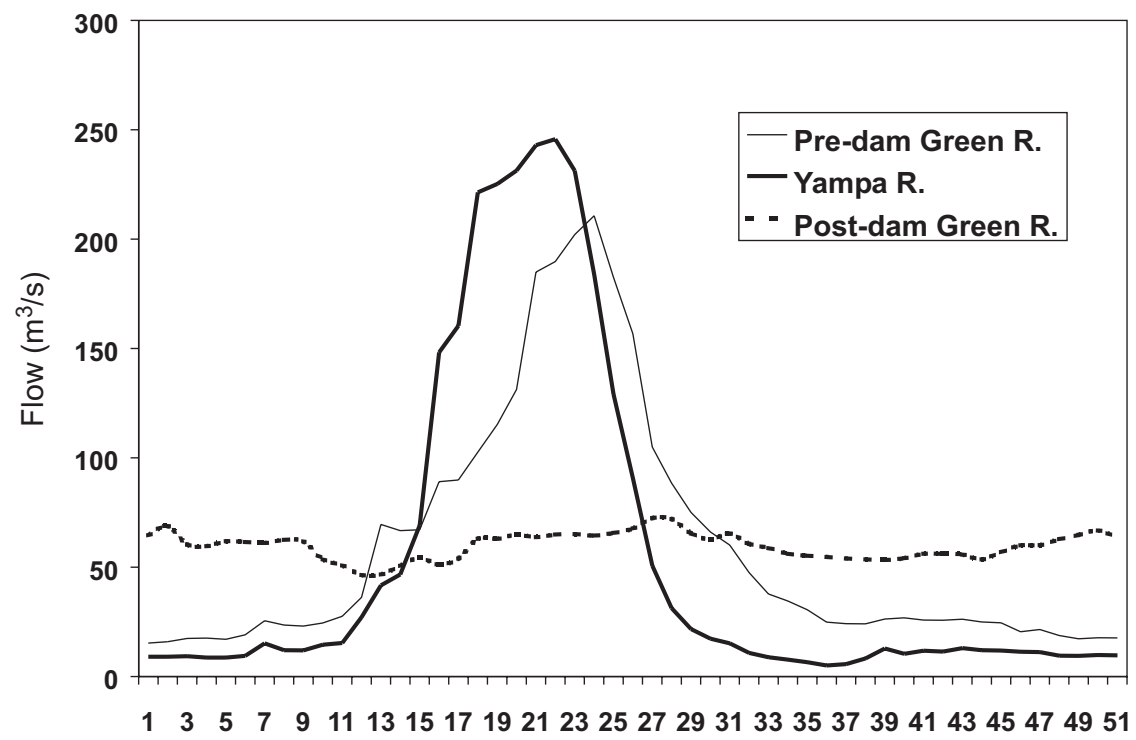

Week of the Year

National Wildlife Refuge. Because of these changes, sandbar willow has shifted from a primarily bank oriented to an island and bank oriented species, and Fremont cottonwood has suffered a severe decline in recruitment (Cooper et al. 1999).

On the Yampa River, Fremont cottonwood depends on the cycle of spring flooding and is generally prolific along banks and point bars (Cooper et al. 1999). Sandbar willow is also found in large patches primarily along the bank. In late summer the river subsides to base flows and remains near that level until the following spring. Base flows expose large sandbars that separate the river from its vegetation.

\section{Methods}

\section{Capture and radiotelemetry}

We used Hancock traps (Hancock Trap Co., Custer, South Dakota) and snares (Gregerson No. 3 with a 16-in. stop to limit captures of nontarget species) to capture beavers during September through November of 1997, 1998, and 1999. Hancock traps were used as our primary trapping method because they are effective at catching all ages and have a lower associated trap mortality than snares (McKinstry and Anderson 1998). Snares were ineffective for capturing subadults and juveniles because of the stop. We used snares as a secondary trap, deploying them primarily when trapping with Hancock traps became slow. In 1997 and 1998, we focused on capturing adult animals for radio implants. In 1999, we attempted to capture all members of each colony within each study area. We trapped for $8-10$ nights on each colony and used 4 or 5 Hancock traps and 0-40 snares. We trapped for three periods on the Green River (22-29 September, 11-19 October, and 30 October 6 November) and two periods on the Yampa River (1-9 and 20-29 October) and alternated our trapping sessions between rivers.

All captured animals were weighed and marked with ear tags (Monel No. 1005-3; National Band \& Tag Company, Newport, Ky.), and sexed through external palpation for a baculum (Osborn 1955) and a check of anal-sac fluid (Schulte et al. 1995). The following body measurements were taken: total length (from the tip of the nose to the end of the tail), breadth of the zygomatic arch, length of the tail (from the base to the end of the tail), width of the tail (at the widest part), and thickness of the tail (at the midline, $2.5 \mathrm{~cm}$ distal to the base of the tail). Beavers weighing $\geq 16 \mathrm{~kg}$ were considered adults (3+ years old), those weighing $8-16 \mathrm{~kg}$ were considered subadults (1-2 years old), and those weighing $<8 \mathrm{~kg}$ were considered juveniles ( $<1$ year old) (Patric and Webb 1960). We substantiated the $16-\mathrm{kg}$ cutoff for adults by recapturing and weighing 3 animals in 1999 that were caught as juveniles in 1997 ( 1 from the Green River and 2 from the Yampa River); all weighed $>16 \mathrm{~kg}$ in 1999 .

We implanted transmitters in 15 adult beavers in the fall of 1997 ( 8 on the Green River and 7 on the Yampa River). In 1998 we implanted transmitters in 2 additional animals on the Green River and 1 on the Yampa River. We attempted to implant transmitters in adult mating pairs from each colony in our study areas. We used isofluorine and sevofluorine gas anesthesia (a new procedure for beavers; S. Breck, unpublished data) for surgery and implanted radio transmitters (Advanced Telemetry Systems, Isanti, Minn.; $33 \mathrm{~mm}$ wide $\times 109 \mathrm{~mm}$ long, $100 \mathrm{~g}$; expected transmitter life 3 years) in the peritoneal cavity (Davis et al. 1984; Smith et al. 1991). We provided water to individuals post surgery and allowed them to recover for up to $8 \mathrm{~h}$, then immediately released them at the site of capture. The Colorado State University Animal Care and Use Committee approved our trapping and handling protocol (No. 97-018A-04).

We monitored radio-equipped animals to assess activity and estimate home-range size. To estimate home-range size we monitored intensively from May through June in 1998 and 1999. During these periods we monitored a single animal or family pair through the night. Individuals were located before sundown, at which time we attempted to obtain a location every $15 \mathrm{~min}$. To obtain locations we followed an individual along the shore until the signal was perpendicular to the river. Because we were often unable to determine the precise location of the animal, we plotted the location as a line across the river on a topographic map or a map generated from aerial photographs. We entered these lines into a geographic information system (GIS) coverage using ArcView. The line coverage was converted to a point coverage by cropping each line to the river margins and then calculating the midpoint of each line (i.e., the 
points were justified to the middle of the river). The points constituted the Cartesian coordinates that were used in the home-range analysis described below.

\section{Analysis}

Body size

We used a two-tailed $t$ test with equal variances (PROC TTEST; SAS Institute Inc. 1990) to test for differences in body mass, total body length, tail length, tail width, tail thickness, and zygomaticarch breadth for beavers between rivers. Adults, subadults, and juveniles were tested separately. We report actual significance levels.

\section{Density}

We took a census of the number of colonies per linear kilometre of river in 1997, 1998, and 1999. Designation of a colony was based on the presence of an adult mating pair and evidence of an active den. This was determined by finding fresh sign near dens and trapping in 1997, and by finding fresh sign near dens, trapping, and radiotelemetry in 1998 and 1999. For measuring density we used the telemetry data to define the extent of the study area by taking the farthest upstream and downstream telemetry locations. We excluded 1 colony located at the upstream end of the study area just below the confluence with the Little Snake River. Monitoring revealed that the beavers utilized the Little Snake River, but because of logistical constraints we were unable to accurately monitor locations on this river, so they were eliminated from our analyses of density and home-range size.

\section{Home-range sizes}

Sauer et al. (1999) described a method for analyzing homerange sizes of animals that move in a linear fashion (e.g., river otters, beavers, and muskrats restricted to a river). In this procedure the linear length is used for home-range size rather than the area contained within a contour to avoid the bias of including large areas of land where an animal would not occur. We used a modified version of this technique to calculate the home-range sizes of beaver colonies on the Green and Yampa rivers. The locations of adult beavers occupying the same colony were combined but separated by year (1998 and 1999). These Cartesian coordinates were used in the program The Home Ranger (written by F. Hovey, Illinois Natural History Survey Wildlife Ecology Software server, http:// nhsbig.inhs.uiuc.edu/) to generate 95,75 , and $50 \%$ probability contour intervals. We used the program's fixed kernel estimator with a grid size of $100 \times 100$ and a smoothing parameter picked by the program according to the least-squares cross-validation score. The contour intervals generated by the program were transferred to a GIS to create a coverage that overlaid the original midpoint locations of beavers. Following the line generated by the midpoints, we measured the linear length of river between the points of intersection of the contours and the midline in the river. When there was more than one polygon for a single contour, we included the distance between the polygons as part of the home range (Sauer et al. 1999). We calculated a linear home-range length for each colony at each probability contour interval $(95,75$, and $50 \%)$. Owing to the small number of home ranges, we pooled family groups across years and used a $t$ test (PROC TTEST; SAS Institute Inc. 1990) to test whether the home range was smaller on the Yampa River.

\section{Results}

We had 1 and 2 trap mortalities in 1997 and 1999, respectively. All mortalities were adult beavers caught in snares on the Green River. In 1999, the trapping effort (number of trap-nights per colony) was similar when Hancock traps were used (Green River: $\bar{x}=37.5, \mathrm{SE}=4.69$; Yampa River: $\bar{x}=$ 38.3, $\mathrm{SE}=11.58)$ but higher on the Green River when snares were used (Green River: $\bar{x}=81.0 \mathrm{SE}=30.4$; Yampa River: $\bar{x}=47.5, \mathrm{SE}=47.5)$. In the fall of 1998, 2 radio-equipped beavers and 1 unmarked adult beaver on the Yampa River were killed, presumably by a mountain lion. We did not find any of our radio-equipped animals killed by predators on the Green River.

\section{Body condition}

Adult beavers on the Green River were larger in 3 of the 6 body measurements: body mass, tail thickness, and tail width ( $p<0.03$ in all cases; Table 1). The other 3 measurements (including the two skeletal measurements, total length and zygomatic-arch breadth) showed little or no difference. Subadult beavers on the Green River were larger in 4 of the 6 body measurements: body mass, tail thickness, tail length, and total length $(p<0.03$ in all cases; Table 1$)$. Tail width and zygomatic-arch breadth showed no difference. Juvenile beavers on the Green River were smaller for 2 of the 6 measurements: tail length and zygomatic-arch breadth $(p<0.03$ in all cases; Table 1). The other 4 measurements showed no difference.

\section{Density}

Based on telemetry, the lengths of the study reaches over 2 years, excluding 1 colony on the Yampa River, were $8.6 \mathrm{~km}$ for the Yampa River and $10.1 \mathrm{~km}$ for the Green River. Calculations indicated a higher density of beavers on the Green River (0.50-0.60 colonies per kilometre of river) than on the Yampa River $(0.35$ colonies per kilometre of river). The number of colonies on the Yampa River, 3, was consistent over the three fall seasons of trapping and two spring seasons of monitoring. On the Green River the number of colonies was at least 5 and there was evidence that in 1999 a sixth colony was becoming established.

\section{Home-range size}

In two seasons, 1998 and 1999, we calculated a total of 5 and 7 home ranges on the Yampa River and Green River, respectively. There was no evidence that home-range lengths differed between the rivers for any of the 3 probability contour intervals (Table 2). Home-range length was extremely variable on both rivers (e.g., 95\% contour interval: Yampa River: range $=1.55-2.95 \mathrm{~km}, \mathrm{SE}=0.232 \mathrm{~km}$; Green River, range $=1.16-4.48 \mathrm{~km}, \mathrm{SE}=0.457 \mathrm{~km}$ ).

\section{Discussion}

Vanden Berge and Vohs (1977) compared populations of bank-dwelling beavers in bank-stabilized and free-flowing portions of the Missouri River. They found that stabilization decreased the density of beavers and ascribed this to habitat alteration, though they did not discuss what aspect of the habitat was altered. Our original hypotheses followed a similar premise that flow regulation caused a decrease in cottonwoods and resulted in a negative demographic response from beaver populations. Instead we found evidence that flow regulation on the Green River has had a positive influence on the demographic response of beavers in the alluvial section below Flaming Gorge Dam. We believe that this is 
Table 1. Comparison (using two-tailed $t$ tests) of body measurements of adult, subadult, and juvenile beavers (Castor canadensis) captured during fall in 1997-1999 on the Green and Yampa rivers in northwestern Colorado.

\begin{tabular}{|c|c|c|c|c|c|c|c|c|}
\hline & \multicolumn{3}{|c|}{ Green River } & \multicolumn{3}{|c|}{ Yampa River } & \multirow[b]{2}{*}{$t$} & \multirow[b]{2}{*}{$P$} \\
\hline & $\bar{x}$ & SE & $N$ & $\bar{x}$ & SE & $N$ & & \\
\hline \multicolumn{9}{|l|}{ Adult beavers } \\
\hline Tail thickness $(\mathrm{cm})$ & 4.15 & 0.12 & 20 & 3.76 & 0.10 & 14 & 2.33 & 0.026 \\
\hline Tail width $(\mathrm{cm})$ & 15.34 & 0.28 & 20 & 14.17 & 0.27 & 14 & 2.88 & 0.007 \\
\hline Tail length (cm) & 28.0 & 0.39 & 20 & 27.78 & 0.41 & 14 & 0.36 & 0.719 \\
\hline \multicolumn{9}{|l|}{ Subadult beavers } \\
\hline Body mass (kg) & 14.33 & 0.61 & 6 & 12.38 & 0.28 & 8 & 3.21 & 0.008 \\
\hline Tail thickness $(\mathrm{cm})$ & 3.33 & 0.13 & 6 & 2.96 & 0.08 & 7 & 2.59 & 0.025 \\
\hline Tail width $(\mathrm{cm})$ & 12.77 & 0.75 & 6 & 11.79 & 0.15 & 7 & 1.39 & 0.192 \\
\hline Tail length (cm) & 25.85 & 0.66 & 6 & 24.01 & 0.33 & 7 & 2.61 & 0.024 \\
\hline Body mass (kg) & 5.58 & 0.31 & 8 & 5.67 & 0.22 & 16 & 0.24 & 0.812 \\
\hline Tail thickness $(\mathrm{cm})$ & 2.19 & 0.10 & 8 & 2.07 & 0.06 & 16 & 1.10 & 0.283 \\
\hline Tail width $(\mathrm{cm})$ & 8.25 & 0.38 & 8 & 7.85 & 0.21 & 16 & 1.01 & 0.325 \\
\hline Tail length (cm) & 17.36 & 0.56 & 8 & 18.98 & 0.43 & 16 & 2.24 & 0.036 \\
\hline Total length $(\mathrm{cm})$ & 69.46 & 1.65 & 8 & 71.16 & 1.00 & 16 & 0.92 & 0.365 \\
\hline Zygomatic-arch breadth (cm) & 7.94 & 0.11 & 7 & 8.33 & 0.10 & 16 & 2.40 & 0.026 \\
\hline
\end{tabular}

Table 2. Mean linear home-range sizes of beavers in spring 1998 and 1999 on the Green and Yampa rivers.

\begin{tabular}{|c|c|c|c|c|}
\hline & \multicolumn{2}{|c|}{ Home-range size $(\mathrm{km})$} & \multirow[b]{2}{*}{$\mathrm{df}$} & \multirow[b]{2}{*}{$P$} \\
\hline & Mean & SE & & \\
\hline \multicolumn{5}{|l|}{$95 \%$ contour } \\
\hline Green River & 2.19 & 0.457 & & \\
\hline Yampa River & 2.38 & 0.232 & 10 & 0.755 \\
\hline Difference & -0.19 & 0.581 & & \\
\hline \multicolumn{5}{|l|}{$75 \%$ contour } \\
\hline Green River & 1.81 & 0.425 & & \\
\hline Yampa River & 2.24 & 0.225 & 10 & 0.445 \\
\hline Difference & -0.43 & 0.543 & & \\
\hline \multicolumn{5}{|l|}{$50 \%$ contour } \\
\hline Green River & 1.25 & 0.464 & & \\
\hline Yampa River & 1.01 & 0.289 & 10 & 0.702 \\
\hline Difference & 0.24 & 0.606 & & \\
\hline
\end{tabular}

due primarily to changes in distribution and availability of willow as a result of changes in fluvial geomorphology (Breck 2001).

Body mass and tail size have been used as indicators of body condition in beavers (Aleksiuk 1970; Smith and Jenkins 1997). Smith and Jenkins (1997) demonstrated that body mass and tail size of beavers decreased during winter and that the extent of the decrease varied between years and colonies depending on environmental conditions and the availability of food. Similarly, we demonstrated differences in body mass and tail size for adults and subadults between rivers, which may also be explained by differences in food availability and environmental conditions caused by flow regulation.
On the Yampa River, subadults and adults had lower body mass and smaller tails ( 2 out of the 3 measurements; Table 1) relative to subadult and adult beavers on the Green River, indicating that beavers on the Yampa River were in poorer condition. This result could be misleading if adult beavers on the Yampa River were generally smaller than beavers on the Green River. However, neither of the 2 adult skeletal measurements (zygomatic-arch breadth and total length) differed between rivers (Table 1), indicating that beavers on the Yampa River were growing to a similar size but not storing as much fat as beavers on the Green River and therefore were in poorer condition.

One factor that may have lowered the condition of beavers on the Yampa River was the higher cost of obtaining woody forage during the fall. Though the abundance of cottonwood and willow was greater on the Yampa River, the availability of cottonwood and willow on the Yampa River declined each year in late summer through late winter as the river returned to base flow. Each fall we observed beaver trails, varying from a few metres to $50 \mathrm{~m}$, crossing sandy flats and sandbars to reach woody forage (S. Breck, personal observation). This overland travel to obtain forage likely increased beavers' expenditure of energy (Basey and Jenkins 1995) that otherwise could have been stored as fat. On the Green River, though cottonwood was limited in abundance, the availability of willow was greater, owing to the stable flows and the redistribution of willow onto islands. Beavers utilized over twice as much willow on the Green River as on the Yampa River (Breck 2001), which required little or no overland travel and reduced energy expenditure for traveling.

Another explanation for the lower body condition of beavers on the Yampa River was that over-winter conditions (ice 
cover) differed widely between rivers. The surface of the Yampa River froze solid for varying periods each winter during the study, whereas the surface of the Green River remained open because of numerous factors associated with flow regulation. One observed consequence of this difference was that food caches were smaller on the Green River than on the Yampa River (S. Breck, personal observation). We can only speculate on the effect of differences in food caching on the energetics of beavers, but it is conceivable that the energy expenditure of beavers on the Green River was lower because they were able to forage year-round without incurring the energy cost of building a large cache.

In contrast to the older age-classes, juvenile beavers on the Yampa River were as large as or larger than juvenile beavers on the Green River in terms of all body measurements. This result implies that juvenile beavers on the Yampa River were attaining a positive caloric balance as great as or greater than that of juvenile beavers on the Green River. This is only partly explained by the greater availability of forage during the flood period on the Yampa River, because we trapped and took body measurements in September and October, after the Yampa River had been at base flow for 2 or 3 months and thus the availability of forage had declined. Another explanation is that juvenile beavers maintained growth in the fall by utilizing proportionately more of the stored food cache than adults and subadults (Novakowski 1967; Smith and Jenkins 1997).

The estimates of density $(0.50-0.60$ and 0.35 colonies per kilometre on the Green River and Yampa River, respectively) were based on a census of $10.1 \mathrm{~km}$ on the Green River and $8.6 \mathrm{~km}$ on the Yampa River and densities beyond these sections should not be inferred. However, on the Yampa River, the length of our study reach was confined between the confluence of the Little Snake River and the beginning of the Yampa canyon. Above and below these points were ecosystems that were very different because of geologic and hydrologic differences. The length of our study reach on the Green River was designed to roughly match that on the Yampa River and represents one-quarter of the length of river in Browns Park National Wildlife Refuge.

These estimates are at the lower range of those reported in other studies (see Hill 1982). This may be due to the fact that most studies of beavers were carried out on stream systems where beavers were able to build dams and the availability of forage was greater. Strong (1982) provides the only other data concerning density of beavers on a largeorder arid-land western river. He reported a density of 1.02 beavers $/ \mathrm{km}$ on the alluvial sections of the Rio Grande in Big Bend National Park. If we assume that the colonies in our study contained, on average, 5 beavers (Hill 1982), then density was 2.5 beavers $/ \mathrm{km}$ on the Green River and 1.75 beavers $/ \mathrm{km}$ on the Yampa River, nearly 2-2.5 times the densities found by Strong (1982).

Density of beavers is strongly related to the availability of forage (Jenkins and Busher 1979; Allen 1983; Baker and Cade 1995). On the Yampa River the overall availability of woody forage was much lower than on the Green River, though the abundance of forage was much greater (Breck 2001). This may explain why beaver densities were lower on the Yampa River. Another explanation is that alternative foods were more abundant on the Green River. Merritt and
Cooper (2000) documented the formation of marsh communities on the margin of the Green River that were not present on the Yampa River. These marsh communities possibly provided alternative herbaceous forage for beavers during spring and summer. However, the availability of herbaceous forage likely decreased in winter, when beavers face critical energetic challenges (Dyck and MacArthur 1992). Therefore, even with the presence of alternative herbaceous forages on the Green River, we suggest that the availability of willow is likely very important in explaining the higher density, as beavers would need to rely on woody forage during fall and winter.

Lesica and Miles (1999) speculated that flow regulation might have produced higher populations of beavers on the Marias River. They offered a different explanation for the increased densities, namely that flow regulation enhanced beaver denning habitat. They suggest that flooding is an important cause of beaver mortality and den abandonment (Hill 1982; Nitsche 2001) and thus reduces the density of beavers on rivers that flood. Our data do not support this explanation, as we found beavers to be very adaptable to flooding on the Yampa River by having a spring den, located farther from the center of the river, that was used during the flood stage and a winter den that was used during base flows. Furthermore, our data indicate that during the flood stage, predation risk was minimized because beavers had easy access to preferred foods. In the fall of 1998, 2 radio-equipped beavers and 1 unmarked adult beaver on the Yampa River were killed and eaten, presumably by a mountain lion. All predation events occurred when the Yampa River was at base flow, near or below $30 \mathrm{~m}^{3} / \mathrm{s}$. We argue that greater availability of forage was the primary factor supporting higher densities of beavers on the Green River.

We did not find a difference in home-range size between rivers. However, on the Yampa River we did document large areas between colonies that were not used by radio-equipped beavers and showed very little sign of beaver activity. These unused areas contained woody forage but this forage was made unavailable much of the year by exceptionally large sandbars (over $100 \mathrm{~m}$ ) that formed during base flows. On the Green River the gaps between home ranges were much smaller, if they existed at all. Consequently, there was no difference in home-range size but a lower density of beavers on the Yampa River.

We found a large variation in home-range size between years for each family group and between family groups on each river. Wheatley (1997) apparently carried out the only other published study in which home-range size of beavers in a river environment (i.e., where they are unable to build dams) was measured. Although she quantified home ranges differently, making comparisons between studies difficult, she also recorded a great deal of variability. In our study this variability may be partly explained by the removal of individuals, either through accidental trap mortality or predation events, which allowed beavers in adjacent territories to expand their range. On the Green River, during our first trapping season (fall 1997) 1 large adult male, presumably from an established territory, was killed by a snare. One colony adjacent to this animal had a home range that was $400 \mathrm{~m}$ larger in 1998 (6 months after the trap mortality) than in 1999. Snares killed 2 more beavers in the fall of 1999 on the 
Green River, but these mortalies could not have affected our movement or density results because the mortalities occurred after the home-range data were collected. On the Yampa River, predators killed 2 adults from the same colony in the fall of 1998. After this event occurred, we documented the home range of an adjacent colony expanding by nearly $600 \mathrm{~m}$.

Assessing the demographic response of a population of animals to changes in habitat is a difficult process (Garshelis 2000). In this study we measured 3 demographic variables to assess the effect of flow regulation on beavers. Body condition, density, and movement pattern provided strong evidence that habitat conditions for beavers were better on the Green River than on the Yampa River. Furthermore, there was some evidence that predation pressure was higher for adult beavers on the Yampa River. Thus, owing to the weight of evidence, we argue that flow regulation may have benefited beavers and that the primary factor enhancing beaver populations was the greater availability of willow because of its shift in distribution from a bank-oriented to an islandoriented species.

\section{Acknowledgements}

The U.S. Geologic Survey and the Denver Zoological Foundation funded this research. We thank personnel from the National Park Service and Cross Mountain Ranch for permission to work on the Yampa River, and personnel from Browns Park National Wildlife Refuge for permission to work on the Green River and for the assistance they provided. We thank A. Craig, S. Pavey, M. Andre, D. Neubaum, and C. Nesnow for assistance in the field, H. Seim, J. Gaynor, and $\mathrm{H}$. Brownell for assistance with surgeries, and G. Reese for assistance with the GIS applications. T. Hobbs, J. Detling, D. Kellett, D. Bender, and two anonymous reviewers provided helpful comments on the manuscript.

\section{References}

Aleksiuk, M. 1970. The function of the tail as a fat storage depot in the beaver (Castor canadensis). J. Mammal. 51: 145-148.

Allen, A.W. 1983. Habitat suitability index models: beaver. U.S. Fish and Wildlife Service FWS/OBS-82/10.30 (revised), Fort Collins, Colo.

Andersen, D.C., and Cooper, D.J. 2000. Plant-herbivore-hydroperiod interactions: effects of native mammals on floodplain tree recruitment. Ecol. Appl. 10: 1383-1399.

Andersen, D.C., Wilson, K.R., Miller, M.S., and Falck, M. 2000. Movement patterns of riparian small mammals during predictable floodplain inundation. J. Mammal. 81: 1087-1099.

Andrews, E.D. 1986. Downstream effects of Flaming Gorge Reservoir on the Green River, Colorado and Utah. Geol. Soc. Am. Bull. 97: 1012-1023.

Baker, B.W., and Cade, B.S. 1995. Predicting biomass of beaver food from willow stem diameters. J. Range Manag. 48: 322-326.

Barnes, W.J., and Dibble, E. 1988. The effects of beaver in riverbank forest succession. Can. J. Bot. 66: 40-44.

Basey, J.M., and Jenkins, S.H. 1995. Influences of predation risk and energy maximization on food selection by beavers (Castor canadensis). Can. J. Zool. 73: 2197-2208.

Breck, S.W. 2001. The effects of flow regulation on the populations and ecology of beavers, cottonwood and willow on the
Green and Yampa Rivers in northwestern Colorado. Ph.D. thesis, Colorado State University, Fort Collins.

Busch, D.E., and Smith, S.D. 1995. Mechanisms associated with decline of woody species in riparian ecosystems of the southwestern U.S. Ecol. Monogr. 65: 347-370.

Cooper, D.J., Merritt, D.M., Andersen, D.C., and Chimner, R.A. 1999. Factors controlling the establishment of Fremont cottonwood seedlings on the Upper Green River, USA. Regul. Rivers Res. Manag. 15: 419-440.

Davis, J.R., von Recum, A.F., Smith, D.D., and Guynn, D.C., Jr. 1984. Implantable telemetry in beaver. Wildl. Soc. Bull. 12: 322-324.

Dyck, A.P., and MacArthur, R.A. 1992. Seasonal patterns of body temperature and activity in free-ranging beaver (Castor canadensis). Can. J. Zool. 70: 1668-1672.

Eberhardt, L.L., and Thomas, J.M. 1991. Designing environmental field studies. Ecol. Monogr. 61: 53-73.

Falck, M. 1996. Small mammal population dynamics in riparian zones of regulated versus unregulated rivers in northwestern Colorado. M.S. thesis, Colorado State University, Fort Collins.

Garshelis, D.L. 2000. Delusions in habitat evaluation: measuring use, selection, and importance. In Research techniques in animal ecology controversies and consequences. Edited by L. Boitani and T.K. Fuller. Columbia University Press, New York. pp. 111164.

Hill, E.P. 1982. Beaver (Castor canadensis). In Wild mammals of North America. Edited by J.A. Chapman and G.A. Feldhamer. Johns Hopkins University Press, Baltimore. pp. 256-281.

Howe, W.H., and Knopf, F.L. 1991. On the imminent decline of Rio Grande cottonwoods in central New Mexico. Southwest. Nat. 36: 218-224.

Jenkins, S.H., and Busher, P.E. 1979. Castor canadensis. Mamm. Species No. 120. pp. 1-8.

Johnston, C.A., and Naiman, R.J. 1990. Browse selection by beaver: effects on riparian forest composition. Can. J. For. Res. 20: 1036-1043.

Kingsford, R.T. 2000. Ecological impacts of dams, water diversions and river management on floodplain wetlands in Australia. Austral Ecology, 25: 109-127.

Knopf, F.L., Johnson, R.R., Rich, T., Samson, F.B., and Szaro, R. 1988. Conservation of riparian ecosystems in the United States. Wilson Bull. 100: 272-284.

Lesica, P., and Miles, S. 1999. Russian olive invasion into cottonwood forests along a regulated river in north-central Montana. Can. J. Bot. 77: 1077-1083.

McGinley, M.A., and Whitham, T.G. 1985. Central place foraging by beavers (Castor canadensis): a test of foraging predictions and the impact of selective feeding on the growth form of cottonwoods (Populus fremontii). Oecologia, 66: 558-652.

McKinstry, M.C., and Anderson, S.H. 1998. Using snares to livecapture beaver, Castor canadensis. Can. Field-Nat. 112: 469-473.

Merritt, D.M., and Cooper, D.J. 2000. Riparian vegetation and channel change in response to river regulation: a comparative study of regulated and unregulated streams in the Green River Basin, USA. Regul. Rivers Res. Manag. 16: 543-564.

Miller, M.S. 1998. Ecology of deer mice (Peromyscus maniculatus) and Ord's kangaroo rat (Dipodomys ordii) in riparian zones of regulated versus unregulated rivers in northwestern Colorado. M.S. thesis, Colorado State University, Fort Collins.

Nilsson, C., and Dynesius, M. 1994. Ecological effects of river regulation on mammals and birds: a review. Regul. Rivers Res. Manag. 9: 45-53.

Nilsson, C., Ekbald, A., Gardfjell, M., and Carlberg, B. 1991. 
Long-term effects of river regulation on river margin vegetation. J. Appl. Ecol. 28: 963-987.

Nitsche, K.-A. 2001. Behavior of beavers (Castor fiber albicus Matschie, 1907) during the flood periods. In Proceedings of the Second European Beaver Symposium, Białowieza, Poland, September 2000. Edited by A. Czech and G. Schwab. Carpathian Heritage Society, Krakow, Poland.

Novakowski, N.S. 1967. The winter bioenergetics of a beaver population in northern latitudes. Can. J. Zool. 45: 1107-1118.

Osborn, D.J. 1955. Techniques of sexing beaver, Castor canadensis. J. Mammal. 36: 141-142.

Patric, E.F., and Webb, W.L. 1960. An evaluation of three age determination criteria in live beavers. J. Wildl. Manag. 24: 37-44.

SAS Institute Inc. 1990. SAS/STAT ${ }^{\circledR}$ user's guide, version 6. 4th ed. Vol. 1. SAS Institute Inc., Cary, N.C.

Sauer, T.M., Ben-David, M., and Bowyer, R.T. 1999. A new application of the adaptive-kernel method: estimating linear home ranges of river otters, Lutra canadensis. Can. Field-Nat. 113: 419-424.

Schulte, B.A., Müller-Schwarze, D., and Sun, L. 1995. Using anal gland secretion to determine sex in beaver. J. Wildl. Manag. 59: 614-618.
Scott, M.L., Friedman, J.M., and Auble, G.T. 1996. Fluvial process and the establishment of bottomland trees. Geomorphology, 14: 327-339.

Scott, M.L., Auble, G.T., and Friedman, J.M. 1997. Flood dependency of cottonwood establishment along the Missouri River, Montana, U.S.A. Ecol. Appl. 7: 677-690.

Smith, D.W., and Jenkins, S.H. 1997. Seasonal changes in body mass and size of tail of northern beavers. J. Mammal. 78: 869876.

Smith, D.W., Peterson, R.O., Drummer, T.D., and Sheputis, D.S. 1991. Over-winter activity and body temperature patterns in northern beavers. Can. J. Zool. 69: 2178-2182.

Strong, P.I.V. 1982. Beaver-cottonwood interactions and beaver ecology in Big Bend National Park. M.S. thesis, Oklahoma State University, Stillwater.

Vanden Berge, R.J., and Vohs, P.A., Jr. 1977. Population status of beaver on the free-running Missouri River in southeastern South Dakota. Proc. S.D. Acad. Sci. 56: 230-236.

Wheatley, M. 1997. Beaver, Castor canadensis, home range size and patterns of use in the taiga of southeastern Manitoba: III. Habitat variation. Can. Field-Nat. 111: 217-222. 
Copyright $\odot 2003$ EBSCO Publishing 